\title{
Students' Level of Satisfaction and Their Technological Proficiency Growth in Teacher Education Coursework
}

\author{
Trang Phan \\ California State University Fresno, Fresno, CA, USA \\ ORCID: 0000-0003-0697-8272 \\ Earl Aguilera \\ California State University Fresno, Fresno, CA, USA \\ ORCID: 0000-0002-3694-1406 \\ Susan Tracz \\ California State University Fresno, Fresno, CA, USA \\ ORCID: 0000-0002-8893-040X
}

Received: 8 Mar 2021

Accepted: 21 Sep 2021

\begin{abstract}
Teachers are increasingly expected to demonstrate frequent use of and proficiency with educational technologies in the classroom. Meanwhile, teacher experiences with new technologies prior to their entry into the classroom do not always match these expectations. For many teacher education programs, the solution to this challenge lies in the incorporation of educational technologies into coursework for preservice teachers (PSTs). This study examines PST reported uses and proficiency with educational technologies before and after taking introductory educational coursework. Based on surveys administered at the beginning and end of introductory education courses, the study found that PSTs reported consistent improvement in their technological skills. There were also positive relationships among skills competence and PST outcomes of satisfaction, effectiveness, and usefulness. These findings support existing efforts to incorporate educational technology into teacher certification coursework, while also suggesting ways to expand on these approaches to better support PSTs experience with educational technologies.
\end{abstract}

Keywords: pre-service teachers, technologies, proficiency, coursework, experience

\section{INTRODUCTION}

Teachers are increasingly expected to demonstrate frequent use of and proficiency with educational technologies in the classroom (Mishra \& Kohler, 2006). At the same time, teachers' experiences with new technologies prior to their entry into the classroom do not always match these expectations (Project Tomorrow, 2013). For many teacher education programs, the solution to this challenge lies in the incorporation of educational technologies into pre-service teachers' (PSTs) credentialing coursework (Lei, 2009).

To provide further insight into this challenge and course-based approaches to address it, this study examines PSTs reported uses of and proficiency with educational technologies before and after taking introductory education coursework. Drawing on survey research conducted with pre-service teachers at a large public university in the western U.S., we discuss ways that results support existing efforts to incorporate educational 
technology into teacher certification coursework, while also suggesting ways to expand on these approaches to better support PST experiences with educational technologies.

\section{RESEARCH PURPOSE AND QUESTIONS}

The purpose of this article is to report the results of a survey study designed to investigate PST experiences with technology in their introductory education courses, along with various outcomes of these courses. Specifically, the following research questions were asked:

1. Do PSTs report changes in their frequency of technology use after taking introductory education courses? If so, how?

2. Do PSTs report changes in their technological proficiency after taking the introductory education courses? If so, how?

3. Is there a relationship between PSTs reported post-course frequency of in-course technology use and their perceptions of introductory education course outcomes?

4. Is there a relationship between PSTs reported post-course technological proficiency and their perceptions of introductory education course outcomes?

To address these questions, we primarily report frequencies and percentages from crosstab analyses of survey data from PSTs collected at the beginning and end of one semester of the introductory education coursework. As we discuss in the next section, we conceptualize PSTs frequency of technology use and reported technology proficiency as different dimensions of their learning. The course outcomes we have selected focus on student perceptions of their course experiences.

\section{THEORETICAL FRAMEWORK}

In this article, we frame the technology-enhanced learning (TEL; Kirkwood \& Price, 2014) of PSTs through the lens of Sfard's (1998) two metaphors of learning. In this view, learning can be understood as both a state of acquisition and a process of participation.

In the acquisition-based metaphor, learning, or rather, "having learned," is conceptualized as taking place once something has been acquired - a new piece of information, a new skill, a new habit, or a new disposition (Sfard, 1998). We can see this metaphor operating broadly within approaches such as standardized testing, which aims to discriminate between students who have or have not acquired certain ways of knowing, doing, and being (Serafini, 2000). Within the context of teacher education, we see this metaphor at play through certification programs accompanied by demonstrations of knowledge - often through a portfolio or testbased assessments (Wong \& Glass, 2005).

In participation-based framings, learning is conceptualized as an ongoing process that is inseparable from doing. It is not framed as something to be assessed after the fact, but instead, something to be observed at the moment it is occurring. In a general sense, we can see this metaphor operating in research on communities of practice (e.g., Lave \& Wenger, 1991), affinity spaces (e.g., Gee, 2005), and sites of familybased learning (e.g., Rogoff, 2003). Within teacher education, scholars invoke a participation metaphor of learning when discussing professional learning communities (DuFour \& Eaker, 2009) and inquiry-based approaches to teacher professional learning (Cochran-Smith \& Lytle, 2009).

We agree with Sfard (1998) in her stance that both of these metaphors are essential for understanding the full scope of human learning, and in our case, teacher development in TEL. In this project, an acquisitionbased understanding of learning informs the way we conceptualize PSTs reporting on their own proficiency with educational technologies over time. At the same time, a participation-based understanding of learning underpins our focus on teachers' self-reported frequency of educational technology use before and after their education courses. Ultimately, this project seeks to connect these metaphors by framing an inquiry that explores the connections between teachers' TEL and certain outcomes of their education courses. 


\section{SUPPORTING LITERATURE}

Prior survey research on technology use in PST education has focused on a wide range of issues. These surveys have addressed topics including technology self-efficacy, beliefs about technology, reported technology proficiency, and everyday uses of technology. This literature also demonstrates the ways that technology use in teacher education has changed over time, and suggests that research in the area of technology use in teacher education must be regularly updated to reflect the changing contexts of education.

Recent studies in this area include the work of Tondeur et al. (2017) who used in-depth interviews to explore (1) how beginning teachers integrate technology in their practice and (2) the connections between teachers' technology uses and their pre-service education programs. Their findings suggested that beginning teachers primarily used technological applications for structured learning approaches, though a few did create opportunities for student-centered technology use.

In another study, Farjon et al. (2018) utilized survey methods and regression analyses to map the technology integration of pre-service teachers at the start of their initial teacher education programs. The authors examined the attitudes and beliefs towards technology (will), learning experience in technology use (experience), competency of technology use (skill), and access to technology (tool) of 398 pre-service teachers. The results of regression analyses suggested that the will-skill-tool (WST) model explained the variation in pre-service teachers' technology integration $\left(R^{2}=0.60\right)$. Attitudes and beliefs were found to be the strongest influence, while access to technology was found to be the weakest. In seeking to expand the model, the researchers found that the construct of experience was found to affect technology integration significantly when the measurements were considered as one scale.

Looking more deeply into these experiences, Erduran and Ince (2018) employed qualitative case study research to identify the challenges high-school teachers face when integrating technology into their classes and understand the reasons for these difficulties within the framework of TPCK (Mishra \& Koehler, 2006). Analyzing lecture plans, class observations, semi-structured interviews, and a focus group interview the researchers generated five main headings under which they organized these difficulties: (1) Teaching without planning, (2) Struggles to integrate different types of knowledge, (3) Lack of basic knowledge, (4) Errors in technological knowledge and (5) Lack of field-specific support. In their discussion, the authors focused on the ways that teacher education might better integrate some of these areas into coursework.

A review of related literature by Kirkwood and Price (2014) focused on technology-enhanced learning and teaching in higher education. This review focused on research published between 2005 and 2010 . Within this time frame, the authors identified 47 articles as "related to technologies used for teaching and learning in higher education" (p. 6) and reporting on primary empirical research. The review ultimately reported that while the language of technology enhancement was commonly found across the articles, the means through which this enhancement was pursued varied greatly across studies. Among these approaches were (1) the replication of existing teaching practices through digital technologies, (2) the supplementing of existing teaching practices through digital technologies, and (3) the transformation of teaching/learning processes and outcomes. Other recent research has demonstrated the expansion of mobile devices (e.g., Sung et al., 2016), digital game-based learning (e.g., Tüzün et al., 2017), and Web 2.0 technologies (e.g., Lei, 2009) within teacher education.

While survey research has explored technology use in teacher education through the lens of self-efficacy, professional technology integration, belief patterns, technical proficiency, and reported behavior, additional work is needed to understand how PSTs use of and proficiency with educational technology might develop over the course of their teacher certification experiences. Thus, we offer the present study as an additional empirically grounded and locally situated account of PSTs technology use before and after a contemporary teacher education program, as well as the ways that this technology use might be connected to course outcomes and preservice teacher learning. 
Table 1. Participant enrollment in Fall 2019

\begin{tabular}{llcc}
\hline Course number and mode & Course title & Enrollment Respondents \\
\hline Cl 100 (classroom) (4 sections) & Integration of Technology in the Classroom & 118 \\
Cl 149 (online) (2 sections) & Curriculum, Instruction, \& Technology in Secondary & 88 & 10 \\
& Classrooms & 70 & 14 \\
Cl 149 (classroom) (2 sections) & Curriculum, Instruction, \& Technology in Secondary & 70 \\
& Classrooms & 66 & 38 \\
EHD 180T (classroom) (3 sections) & Community-Based Science Learning & 15 & 1 \\
EHD 180T (classroom) & Understanding and Applying Social Science Content, & \\
(1 section) & Pedagogy, \& Technology in K-12 & 49 & 1 \\
EHD 50 (classroom) (2 sections) & Introduction to Teaching & \\
\hline
\end{tabular}

\section{METHODOLOGY}

Survey research methods are popular and valuable for those wanting to learn about people's attitudes, perceptions, feelings, and behaviors by using a smaller sample selected from a larger population (Blair et al., 2013). Since this study seeks to understand how PSTs use technologies before and after their education coursework, we utilize survey techniques for our data collection. Before beginning this study, IRB approval was secured.

\section{Context and Participants}

This research was conducted at a college of education housed in a public university within a statewide comprehensive university system in the western United States. It is designated as both a Hispanic-Serving Institution (HSI) and an Asian American, Native American, \& Pacific Islander Serving Institution (AANAPISI). About $60 \%$ of students enrolled in the college identify as Hispanic, and approximately $70 \%$ are the first generation in their family to attend college.

The college offers several pathways to a PK-12 teaching credential. The largest of these pathways is the Liberal Studies program, which is the primary route for students to become elementary school teachers by earning a multiple-subject credential. Students, who want to become middle school and high school teachers, can also enroll in the single-subject credential program which serves a wide variety of majors including English, Mathematics, Kinesiology, History, and Science.

Participants in this study are primarily junior and senior undergraduate students. Convenience sampling was used for this study. The criterion for participation was that students were just beginning their teacher education programs and were enrolled in introductory education courses during the Fall 2019 semester. These courses must be completed as a prerequisite to entry into the teacher education programs or tend to be taken early in those programs. All courses are either online or in a computer classroom that gives students access to laptops with Internet connection. Table 1 lists these courses along with the student enrollment counts for the Fall 2019 semester.

\section{Instrumentation}

All the sessions of the aforementioned courses (i.e., CI 100, CI 149, EHD 180T, EHD 50) shared the common features that technology was integrated across different assignments in ways that exposed students to instructional technological application demonstration and instructions, and allowed them to demonstrate the tech tool applications in the assignments. For example, an assignment that appeared in all of the courses was for students to use video production software (i.e., iMovie, Movie Maker, Wevideo, etc.) to create a short video for instructional or promotional purposes. For the instructors whose courses involve the promotional video assignment, such a practical technology application in such a specific assignment as promotional video creation could be one-time or multiple times but was one of the most fundamental learning experiences for the students as it reflects the whole cycle of exposure, application, creativity, and transformation. 
Table 2. TEL content by courses

\begin{tabular}{|c|c|c|c|c|c|c|}
\hline \multirow[b]{2}{*}{ Items Assessing TEL } & \multicolumn{6}{|c|}{ Courses } \\
\hline & 100 & $\begin{array}{c}149 \\
\text { Online }\end{array}$ & $\begin{array}{c}149 \\
\text { Classroom }\end{array}$ & $\begin{array}{l}180 T \\
\text { CBSci }\end{array}$ & $\begin{array}{l}180 T \\
\text { SocSci }\end{array}$ & 50 \\
\hline $\begin{array}{l}\text { Searching for, accessing, or using videos to support learning of course } \\
\text { content }\end{array}$ & Yes & Yes & Yes & Yes & Yes & Yes \\
\hline $\begin{array}{l}\text { Preparing and giving presentations (PowerPoint, Google Slides, Prezi, } \\
\text { etc.) }\end{array}$ & Yes & Yes & Yes & Yes & No & Yes \\
\hline Creating and sharing videos (Adobe Spark, Camtasia, YouTube, etc.) & Yes & Yes & Yes & Yes & Yes & Yes \\
\hline $\begin{array}{l}\text { Accessing content, submitting assignments, or communicating with } \\
\text { peers using a Learning Management System (Canvas, Blackboard, etc.) }\end{array}$ & Yes & Yes & Yes & Yes & Yes & Yes \\
\hline Creating and publishing web pages and websites & Yes & Yes & Yes & Yes & No & No \\
\hline $\begin{array}{l}\text { Collaboratively working on a shared online document using Google } \\
\text { Docs, Google Slides, etc. }\end{array}$ & Yes & No & No & Yes & Yes & Yes \\
\hline $\begin{array}{l}\text { Writing and publishing blogs (Weebly, Google Sites, WordPress, Wix, } \\
\text { etc.) }\end{array}$ & Yes & No & No & No & No & No \\
\hline $\begin{array}{l}\text { Conducting research (Google Scholar, Library Databases, ProQuest, } \\
\text { etc.) }\end{array}$ & Yes & No & No & No & No & No \\
\hline $\begin{array}{l}\text { Composing individual essays, reports, or other assignments on a word } \\
\text { processor (Microsoft Word, Google Docs, etc.) }\end{array}$ & Yes & No & No & Yes & Yes & Yes \\
\hline $\begin{array}{l}\text { Contributing, editing, or revising ideas on an existing wiki page online } \\
\text { (Wikipedia, PBWorks, etc.) }\end{array}$ & No & No & No & No & No & No \\
\hline Brainstorming ideas (Mindomo, Bubbl.us, etc.) & Yes & No & No & No & No & No \\
\hline Connecting with others on social media sites (Twitter, etc.) & No & Yes & Yes & No & No & No \\
\hline
\end{tabular}

Both Pre- and Post-Surveys were developed by the authors to explore the state of technology integration in the pre-service education coursework. In preparation to create the survey, the authors studied numerous frameworks of technology-enhanced learning practice, and to establish content validity, a content domain or blueprint of TEL practices was generated by the researchers (Thorkildsen, 2005). This blueprint was then examined across courses to ensure that practices or items represented in the theoretical framework of TEL practices were included in the survey. This was checked and verified by the researchers, and Table 2 presents these results. All specific TEL practices are represented in at least one course except for "Contributing, editing, or revising ideas on an existing wiki page online (Wikipedia, PBWords, etc.)", though those skills might be considered the culminating practice to which other skills lead. The Pre- and Post-Surveys are parallel and share the same TEL construct. Pre- and Post-Survey items asked about student uses of technology within and outside their teacher education coursework.

The Pre-Survey had a question about the class each student was currently enrolled in and questions on different aspects of students' participation in technology-enhanced learning (TEL) practices, including (1) their frequency of engaging in various TEL practices, and (2) perceptions of their proficiency level in these TEL practices (i.e., defined as uses of digital technologies to support the development and sharing of new understandings in cognitive, affective, and social dimensions). Participants' reporting on the frequency of their engagement in TEL practices was measured on a four-point (1-4) Likert scale from 1: Never to 4: Regularly. Proficiency refers to the degree of independence participants reported in varying TEL practices and was measured on a five-point (0-4) Likert scale from 0: No Experience to 4: Expert.

There were two parts to the Post-Survey questionnaire. The first part replicated the Pre-Survey to include the same demographic questions about the student's class and a combination of the Likert-scales and openended questions on TEL. In the second part, the survey asked about 1) the students' overall satisfaction with the course(s) (1: Very dissatisfied to 4: Very satisfied), 2) their perceived course effectiveness in achieving its goals (1: Not effective at all to 4: Very effective), and 3) their perceived course usefulness to their career endeavors (1: Not useful at all to 4: Very useful).

The Cronbach's Alpha Coefficients for the Frequency of Engagement and Proficiency variables are reported in Table 3. These coefficients range from .832 to .888 and have reached the acceptable range of being higher 
Table 3. Cronbach's alphas for pre- and post-survey variables

\begin{tabular}{lcc}
\hline Variables & $\begin{array}{c}\text { Pre-Survey Cronbach's Alpha } \\
\text { Coefficient }\end{array}$ & $\begin{array}{c}\text { Post-Survey Cronbach's Alpha } \\
\text { Coefficient }\end{array}$ \\
\hline Frequency of Engaging in TEL Practices & .853 & .832 \\
Student Perceptions of Proficiency Level & .872 & .888 \\
\hline
\end{tabular}

than .700 (Groth-Marnat, 1999). No Cronbach's Alpha Coefficients could be calculated for Student Overall Satisfaction, Perceived Course Effectiveness, or Perceived Course Usefulness as each of these variables consisted of only one item.

\section{Data Collection Procedures}

The Pre-Survey data were collected in the first two weeks of the semester and the Post-Survey data in the final week when the teaching content was complete and the students were finishing their class projects and assignments. All surveys were delivered in a digital format either in face-to-face or online classes. In the faceto-face classes, at least one of the researchers was present during the sessions in which the surveys were administered. During these visits, the researchers related the purpose of the study, secured student consent form, monitored the process, and answered any student questions. For online courses with no classroombased component, the survey link and instructions were sent to the students by their respective instructors.

\section{Data Analysis}

Before data analysis began, all student personal identifying information was scrubbed. The analysis for this study consists of two parts, each with descriptive statistics. The first statistical description focused on the changes in the PSTs' frequency of technology use and their technological proficiency after taking the introductory education courses. The second part focused on the relationships of (1) the PSTs' reported frequency of in-course technology use and (2) their perceptions of post-course technological proficiency for the course outcomes of satisfaction, effectiveness, and usefulness.

To address the changes in the PSTs' frequency of technology use before and after taking the introductory education courses, Pre- and Post-Survey percentages for student frequency of technology uses and their technological proficiency are presented. To address the relationship between the PSTs' reported frequency of technology use and perceptions of post-course technological proficiency of satisfaction, effectiveness, and usefulness, crosstabs were run. However, only a portion of those crosstabs are presented as the frequency of responses for the less desired outcomes were so extremely small that they are negligible.

\section{FINDINGS}

There were 100 students participating in both Pre- and Post-Survey questionnaires. Considering TEL through the lens of social practice theory, we framed our findings in the order of the research questions we initially outlined as follows:

\section{RQ1: Do PSTs Report Changes in their Frequency of Technology Use after Taking Introductory Education Courses? If so, How?}

To address the changes in the PST frequency of use of technology after taking the introductory education courses, we examined the quantitative results generated from the Pre- and Post-Survey Likert-style item, which asked "Outside of your educational courses, how frequently did you use digital technologies to do the following tasks?" For the scope of this paper, we will only present the data from students who used technology on a regular basis. These results are summarized in Table 4.

We found positive changes from Pre-Survey to Post-Survey in all frequency of use of technology items which ranged from $2.0 \%$ to $27.0 \%$ for the PSTs who took the introductory courses. We also noted a slight decrease in student use of social media to connect with one another over the courses from 59 to $54 \%(-5.0 \%)$. 
Table 4. Student frequency of use of digital technologies before and after taking the introductory education courses

\begin{tabular}{|c|c|c|c|}
\hline \multirow[b]{2}{*}{ Items } & \multicolumn{3}{|c|}{ Regularly (\%) } \\
\hline & Pre & Post & $\begin{array}{c}\% \\
\text { difference }\end{array}$ \\
\hline Searching for, accessing, or using videos to support learning of course content & 29.0 & 56.0 & +27.0 \\
\hline Preparing and giving presentations (PowerPoint, Google Slides, Prezi, etc.) & 40.0 & 60.0 & +20.0 \\
\hline Creating and sharing videos (Adobe Spark, Camtasia, YouTube, etc.) & 15.0 & 33.0 & +18.0 \\
\hline $\begin{array}{l}\text { Accessing content, submitting assignments, or communicating with peers using a Learning } \\
\text { Management System (Canvas, Blackboard, etc.) }\end{array}$ & 62.0 & 80.0 & +18.0 \\
\hline Creating and publishing web pages and websites & 9.0 & 25.0 & +16.0 \\
\hline Collaboratively working on a shared online document using Google Docs, Google Slides, etc. & 49.0 & 64.0 & +15.0 \\
\hline Writing and publishing blogs (Weebly, Google Sites, WordPress, Wix, etc.) & 12.0 & 26.0 & +14.0 \\
\hline Conducting research (Google Scholar, Library Databases, ProQuest, etc.) & 45.0 & 58.0 & +13.0 \\
\hline $\begin{array}{l}\text { Composing individual essays, reports, or other assignments on a word processor (Microsoft } \\
\text { Word, Google Docs, etc.) }\end{array}$ & 75.0 & 85.0 & +10.0 \\
\hline $\begin{array}{l}\text { Contributing, editing, or revising ideas on an existing wiki page online (Wikipedia, PBWorks, } \\
\text { etc.) }\end{array}$ & 11.0 & 17.0 & +6.0 \\
\hline Brainstorming ideas (Mindomo, Bubbl.us, etc.) & 16.0 & 18.0 & +2.0 \\
\hline Connecting with others on social media sites (Twitter, etc.) & 59.0 & 54.0 & -5.0 \\
\hline
\end{tabular}

Table 5. Student level of proficiency with TEL practices before and after taking the introductory education courses

\begin{tabular}{|c|c|c|c|}
\hline \multirow[b]{2}{*}{ Items } & \multicolumn{3}{|c|}{ Advance/Expert (\%) } \\
\hline & Pre & Post & $\begin{array}{c}\% \\
\text { Difference }\end{array}$ \\
\hline Searching for, accessing, or using videos to support learning of course content & 52.0 & 69.0 & +17.0 \\
\hline Creating and publishing web pages and websites & 13.0 & 30.0 & +17.0 \\
\hline $\begin{array}{l}\text { Contributing, editing, or revising ideas on an existing wiki page online (Wikipedia, PBWorks, } \\
\text { Wikia, etc.) }\end{array}$ & 12.0 & 27.0 & +15.0 \\
\hline $\begin{array}{l}\text { Collaboratively working on a shared online document with a partner or group (using Google } \\
\text { Docs, Google Slides, etc.) }\end{array}$ & 71.0 & 85.0 & +14.0 \\
\hline Brainstorming ideas (Mindomo, Bubbl.us, etc.)] & 12.0 & 26.0 & +14.0 \\
\hline Writing and publishing blogs (Weebly, Google Sites, WordPress, Wix, etc.) & 17.0 & 30.0 & +13.0 \\
\hline Creating and sharing videos (Adobe Spark, Camtasia, YouTube, etc.) & 26.0 & 38.0 & +12.0 \\
\hline Preparing and giving presentations (PowerPoint, Google Slides, Prezi, etc.) & 73.0 & 84.0 & +11.0 \\
\hline Conducting research (Google Scholar, Library Databases, ProQuest, etc.) & 61.0 & 71.0 & +10.0 \\
\hline $\begin{array}{l}\text { Accessing content, submitting assignments, or communicating with peers using a Learning } \\
\text { Management System (Canvas, Blackboard, etc.) }\end{array}$ & 78.0 & 87.0 & +9.0 \\
\hline $\begin{array}{l}\text { Composing individual essays, reports, or other assignments on a word processor (Microsoft } \\
\text { Word, Google Docs, etc.) }\end{array}$ & 81.0 & 90.0 & +9.0 \\
\hline Connecting with others on social media sites (Twitter, etc.) & 74.0 & 78.0 & +4.0 \\
\hline
\end{tabular}

\section{RQ2: Do the PSTs Report Technological Proficiency after Taking the Introductory Education Courses? If so, How?}

Similarly, to address the PST reported technological proficiency after taking the introductory education courses, we examined the quantitative results generated from the Pre- and Post-Survey Likert-style item, "Please rate your proficiency level for each of the digital tasks (if applicable)," with a 0-4 Likert scale (i.e., 0: no experience and 4: expert). For this research question, the "advanced" (3) and "expert" (4) categories are merged and only this recorded information is presented in Table $\mathbf{5}$ as that captured the vast majority of the student responses.

As shown in Table 5, there were increases in the student perceptions of their technological proficiency for all items. This result is reflected in the percentage increases which ranged from $4.0 \%$ to $17.0 \%$, by the PSTs who 
Table 6. Student reported frequency of uses of technology with their course satisfaction, effectiveness, and usefulness

\begin{tabular}{|c|c|c|c|c|c|c|c|c|c|c|c|c|}
\hline \multirow{3}{*}{ Items } & \multicolumn{4}{|c|}{$\begin{array}{c}\text { Perceived course } \\
\text { satisfaction }\end{array}$} & \multicolumn{4}{|c|}{$\begin{array}{l}\text { Perceived Course } \\
\text { effectiveness }\end{array}$} & \multicolumn{4}{|c|}{$\begin{array}{c}\text { Perceived Course } \\
\text { usefulness }\end{array}$} \\
\hline & \multicolumn{2}{|c|}{ Sometimes } & \multicolumn{2}{|c|}{ Regularly } & \multicolumn{2}{|c|}{ Sometimes } & \multicolumn{2}{|c|}{ Regularly } & \multicolumn{2}{|c|}{ Sometimes } & \multicolumn{2}{|c|}{ Regularly } \\
\hline & $\mathrm{n}$ & $\%$ & $\mathrm{n}$ & $\%$ & $\mathrm{n}$ & $\%$ & $\mathrm{n}$ & $\%$ & $\mathrm{n}$ & $\%$ & $\mathrm{n}$ & $\%$ \\
\hline $\begin{array}{l}\text { Composing assignments on Word, Google } \\
\text { Docs, etc. }\end{array}$ & 11 & 12.0 & 81 & 88.0 & 11 & 11.7 & 82 & 87.2 & 10 & 10.8 & 83 & 89.2 \\
\hline $\begin{array}{l}\text { Accessing content, submitting assignments, } \\
\text { or communicating with peers using an LMS }\end{array}$ & 15 & 16.3 & 76 & 82.6 & 15 & 16.0 & 76 & 80.9 & 15 & 16.1 & 76 & 81.7 \\
\hline $\begin{array}{l}\text { Collaboratively working on a shared online } \\
\text { document }\end{array}$ & 29 & 31.5 & 60 & 65.2 & 29 & 30.9 & 61 & 64.9 & 28 & 30.1 & 62 & 66.7 \\
\hline $\begin{array}{l}\text { Preparing and giving presentations } \\
\text { (PowerPoint, Google Slides, Prezi, etc.) }\end{array}$ & 27 & 29.3 & 57 & 6.02 & 27 & 28.7 & 58 & 61.7 & 26 & 28.0 & 59 & 63.4 \\
\hline $\begin{array}{l}\text { Conducting research (Google Scholar, } \\
\text { Library Databases, ProQuest, etc.) }\end{array}$ & 27 & 29.3 & 54 & 58.7 & 27 & 28.7 & 56 & 59.6 & 26 & 8.0 & 56 & 60.2 \\
\hline $\begin{array}{l}\text { Searching/ accessing/using } \\
\text { support course content lear }\end{array}$ & 27 & 29.3 & 54 & 58.7 & 29 & 30.9 & 53 & 56.4 & 28 & 30.1 & 54 & 58.1 \\
\hline $\begin{array}{l}\text { Connecting with others on social media sites } \\
\text { (Twitter, etc.) }\end{array}$ & 21 & 22.8 & 49 & 53.3 & 20 & 21.3 & 51 & 54.3 & 20 & 21.5 & 52 & 55.0 \\
\hline $\begin{array}{l}\text { Creating and sharing videos (Adobe Spark, } \\
\text { Camtasia, YouTube, etc.) }\end{array}$ & 25 & 27.2 & 32 & 34.8 & 23 & 24.5 & 33 & 35.1 & 23 & 24.7 & 33 & 35.5 \\
\hline $\begin{array}{l}\text { Writing and publishing blogs (Weebly, } \\
\text { Weebly, Google Sites, WordPress, Wix, etc.) }\end{array}$ & 27 & 29.3 & 26 & 28.3 & 27 & 28.7 & 26 & 27.7 & 28 & 30.1 & 26 & 28.0 \\
\hline $\begin{array}{l}\text { Creating and publishing web pages and } \\
\text { websites }\end{array}$ & 23 & 25.0 & 25 & 27.2 & 23 & 24.5 & 24 & 25.5 & 23 & 24.7 & 24 & 25.8 \\
\hline $\begin{array}{l}\text { Brainstorming ideas (Mindomo, Bubbl.us, } \\
\text { etc.) }\end{array}$ & 22 & 23.9 & 18 & 19.6 & 24 & 25.5 & 18 & 19.1 & 24 & 25.8 & 18 & 19.4 \\
\hline $\begin{array}{l}\text { Contributing, editing, or revising ideas on an } \\
\text { existing wiki page online (Wikipedia, } \\
\text { PBWorks, Wikia, etc.) }\end{array}$ & 16 & 17.4 & 17 & 18.5 & 16 & 17.0 & 17 & 18.1 & 16 & 17.2 & 17 & 18.3 \\
\hline
\end{tabular}

took the introductory courses (Pre- and Post). It is notable that no proficiencies decreased over the time of these courses.

\section{RQ3: Is There a Relationship Between the PST Reported Post-course Frequency of In-course Technology Use and Their Perceptions of Introductory Education Course Outcomes?}

In exploring possible relationships between the PST reported frequency of use of certain technological tools with the introductory educational course outcomes, crosstabs were run between the survey questions about student reported frequency of use of technology (i.e., 0: never and 3: regularly) and the outcome questions about student perceived overall course satisfaction, course effectiveness, and course usefulness, respectively. To focus the scope of this paper, we only present students' actual use of technology (i.e., 2 "sometimes" and 3 "regularly") with the combined ratings of 3 "satisfied, effective, useful" and 4 "very satisfied, very effective, very useful" on their perceived course satisfaction, effectiveness, and usefulness. This decision was made because the overwhelming majority of student responses fell in these categories. The results are summarized in Table 6.

As Table 6 shows, there are relationships, reflected in the number of responses and the percentages, between the PST frequency of use of certain technologies and their overall satisfaction of the course, as well as their perceptions of course effectiveness and usefulness. The percentages are arranged in descending order by course satisfaction. For this study, we consider the regular frequency of usage of $80 \%-100 \%$ to be a strong relationship, $60 \%-79 \%$ moderate, and $59 \%$ and below a weak relationship. The strength of the use of technologies is remarkably consistent among the outcome variables of satisfaction, effectiveness, and usefulness. 
Of the skill practices we assessed in course satisfaction, two of them have strong relationships: Composing assignments on Word, Google Docs, etc. (88.0\%), and Accessing content, submitting assignments, or communicating with peers using an LMS (82.6\%). Two have moderate relationships: Collaboratively working on a shared online document (65.2\%), and Preparing and giving presentations (PowerPoint, Google Slides, Prezi, etc., 62.0\%). We also have three weaker relationships: Conducting research (Google Scholar, Library Databases, ProQuest, etc., 58.7\%), Searching/ accessing/using videos to support course content learning" (58.7\%), and Connecting with others on social media sites (Twitter, etc., 53.3\%). The remaining techniques have percentages less than $50 \%$.

On students' perceived course effectiveness, two skills show strong relationships: Composing assignments on Word, Google Docs, etc. (87.2\%) and Accessing content, submitting assignments, or communicating with peers using an LMS (80.9\%). Two have moderate relationships: Collaboratively working on a shared online document (64.9\%), and Preparing and giving presentations (PowerPoint, Google Slides, Prezi, etc., 61.7\%). Three have weaker relationships: Conducting research (Google Scholar, Library Databases, ProQuest, etc.59.6\%), Searching/accessing/using videos to support course content learning (6.43\%), and Connecting with others on social media sites (Twitter, etc.54.3\%). The other technologies have percentages less than $50 \%$.

Last of all, on students' perceived course usefulness, two skills show strong relationships: Composing assignments on Word, Google Docs, etc. (89.2\%), and Accessing content, submitting assignments, or communicating with peers using an LMS (81.7\%). The three moderate relationships respectively are Collaboratively working on a shared online document (66.7\%), Preparing and giving presentations (PowerPoint, Google Slides, Prezi, etc., 63.4\%), and Conducting research (Google Scholar, Library Databases, ProQuest, etc., 60.2\%). The two weaker relationships are Searching/ accessing/using videos to support course content learning $(58.1 \%)$, and Connecting with others on social media sites (Twitter, etc., 55.9\%). All other technologies items are less than $50 \%$.

\section{RQ 4: Is There a Relationship Between the PST Reported Post-course Technological Proficiency and Their Perceptions of Introductory Education Course Outcomes?}

Similarly, to explore possible relationships between the PST reported technological proficiency with their perceptions of introductory education course outcomes, crosstabs were run between the survey questions about reported technological proficiency (i.e., 0: no experience and 4: expert) and questions on student perceived course satisfaction, effectiveness, and usefulness, respectively. Due to very low frequencies for other response options, for this research question, only high student proficiency of technology results (i.e., 3 "intermediate" and 4 "advanced/expert") with the combined ratings (i.e., 3 "satisfied, effective, useful" and 4 "very satisfied, very effective, very useful") on perceived course satisfaction, perceived course effectiveness, and perceived usefulness, respectively, are presented. This decision was based on high percentages of student responses in these categories and negligible responses of other categories. These results appear in Table 7.

As Table 7 shows, there are strong and consistent relationships, reflected in the number of responses and percentages, between the high PST reported post-course technological proficiency and their overall satisfaction of the course, as well as their perception of course effectiveness and usefulness. These percentages are arranged in descending order of student perceived course satisfaction. The same ranges applied for the relationships as previously described in RQ3 are used here (i.e., strong $80-100 \%$, moderate $60-70 \%$, weak 59\%, and below).

Of the skill practices we assessed, four of them have strong relationships with the student's perceived course satisfaction: Composing assignments on Word, Google Docs, etc. (89.1\%), Accessing content, submitting assignments, or communicating with peers using an LMS (87.0\%), Collaboratively working on a shared online document (84.8\%), and Preparing and giving presentations (PowerPoint, Google Slides, Prezi, etc., 83.7\%). Two have moderate relationships: Connecting with others on social media sites (Twitter, etc., 78.3\%), and Conducting research (Google Scholar, Library Databases, ProQuest, etc., 71.7\%). One item has a weak 
Table 7. Student reported technological proficiency and their perceived course satisfaction, effectiveness, and usefulness

\begin{tabular}{|c|c|c|c|c|c|c|c|c|c|c|c|c|}
\hline \multirow{3}{*}{ Items } & \multicolumn{4}{|c|}{$\begin{array}{c}\text { Perceived course } \\
\text { satisfaction }\end{array}$} & \multicolumn{4}{|c|}{$\begin{array}{l}\text { Perceived Course } \\
\text { effectiveness }\end{array}$} & \multicolumn{4}{|c|}{$\begin{array}{l}\text { Perceived Course } \\
\text { usefulness }\end{array}$} \\
\hline & \multicolumn{2}{|c|}{ Intermediate } & \multicolumn{2}{|c|}{$\begin{array}{l}\text { Advanced } \\
\text { / Expert }\end{array}$} & \multicolumn{2}{|c|}{ Intermediate } & \multicolumn{2}{|c|}{$\begin{array}{l}\text { Advanced } \\
\text { / Expert }\end{array}$} & \multicolumn{2}{|c|}{ Intermediate } & \multicolumn{2}{|c|}{$\begin{array}{l}\text { Advanced } \\
\text { / Expert }\end{array}$} \\
\hline & $n$ & $\%$ & $n$ & $\%$ & $n$ & $\%$ & $n$ & $\%$ & $\mathrm{n}$ & $\%$ & $\mathrm{n}$ & $\%$ \\
\hline $\begin{array}{l}\text { Composing assignments on Word, Google } \\
\text { Docs, etc. }\end{array}$ & 10 & 10.9 & 82 & 89.1 & 9 & 9.6 & 85 & 90.4 & 9 & 9.7 & 84 & 90.3 \\
\hline $\begin{array}{l}\text { Accessing content, submitting assignments, } \\
\text { or communicating with peers using an LMS }\end{array}$ & 9 & 9.8 & 80 & 87.0 & 9 & 9.6 & 82 & 87.2 & 8 & 8.6 & 82 & 88.2 \\
\hline $\begin{array}{l}\text { Collaboratively working on a shared online } \\
\text { document }\end{array}$ & 11 & 12.0 & 78 & 84.8 & 10 & 10.6 & 81 & 86.2 & 9 & 9.7 & 81 & 87.1 \\
\hline $\begin{array}{l}\text { Preparing and giving presentations } \\
\text { (PowerPoint, Google Slides, Prezi, etc.) }\end{array}$ & 13 & 14.1 & 77 & 83.7 & 12 & 12.8 & 80 & 85.1 & 12 & 12.9 & 79 & 84.9 \\
\hline $\begin{array}{l}\text { Connecting with others on social media sites } \\
\text { (Twitter, etc.) }\end{array}$ & 14 & 15.2 & 72 & 78.3 & 13 & 13.8 & 74 & 78.7 & 13 & 14.0 & 74 & 79.6 \\
\hline $\begin{array}{l}\text { Conducting research (Google Scholar, } \\
\text { Library Databases, ProQuest, etc.) }\end{array}$ & 23 & 2.0 & 66 & 71.7 & 23 & 24.5 & 68 & 72.3 & 23 & 24.7 & 67 & 72.0 \\
\hline $\begin{array}{l}\text { Searching/ accessing/using videos to } \\
\text { support course content learning }\end{array}$ & 22 & 23.9 & 63 & 68.5 & 22 & 23.4 & 65 & 69.1 & 22 & 23.7 & 64 & 68.8 \\
\hline $\begin{array}{l}\text { Creating and sharing videos (Adobe Spark, } \\
\text { Camtasia, YouTube, etc.) }\end{array}$ & 34 & 37.0 & 37 & 40.2 & 36 & 38.3 & 36 & 38.3 & 35 & 37.6 & 37 & 39.8 \\
\hline $\begin{array}{l}\text { Creating and publishing web pages and } \\
\text { websites }\end{array}$ & 30 & 32.6 & 30 & 32.6 & 31 & 33.0 & 29 & 30.9 & 31 & 33.3 & 30 & 32.3 \\
\hline $\begin{array}{l}\text { Writing and publishing blogs (Weebly, } \\
\text { Weebly, Google Sites, WordPress, Wix, etc.) }\end{array}$ & 32 & 34.8 & 29 & 31.5 & 34 & 36.2 & 29 & 30.9 & 34 & 36.6 & 30 & 32.3 \\
\hline $\begin{array}{l}\text { Contributing, editing, or revising ideas on an } \\
\text { existing wiki page online (Wikipedia, } \\
\text { PBWorks, Wikia, etc.) }\end{array}$ & 18 & 19.6 & 25 & 27.2 & 18 & 19.1 & 27 & 28.7 & 18 & 19.4 & 27 & 29.0 \\
\hline $\begin{array}{l}\text { Brainstorming ideas (Mindomo, Bubbl.us, } \\
\text { etc.) }\end{array}$ & 26 & 28.3 & 25 & 27.2 & 28 & 29.8 & 26 & 27.7 & 28 & 30.1 & 26 & 28.0 \\
\hline
\end{tabular}

relationship: Searching/accessing/using videos to support course content learning (68.5\%). Several items have percentages less than $50 \%$.

On student perceived course effectiveness, four skills show strong relationships: Composing assignments on Word, Google Docs, etc. (90.4\%), Accessing content, submitting assignments, or communicating with peers using an LMS (87.2\%), Collaboratively working on a shared online document (86.2\%), and Preparing and giving presentations (PowerPoint, Google Slides, Prezi, etc., 85.1\%). Three have moderate relationships: Connecting with others on social media sites (Twitter, etc., 78.7\%), Conducting research (Google Scholar, Library Databases, ProQuest, etc., $72.3 \%$ ), and Searching/accessing/using videos to support course content learning (69.1\%). All other items have percentages less than $50 \%$.

Last of all, on students' perceived course usefulness, four skills show strong relationships: Composing assignments on Word, Google Docs, etc. (90.5\%), Accessing content, submitting assignments, or communicating with peers using an LMS (88.2\%), Collaboratively working on a shared online document (87.1\%), and Preparing and giving presentations (PowerPoint, Google Slides, Prezi, etc., 84.9\%). The three moderate relationships respectively are Connecting with others on social media sites (Twitter, etc., 79.6\%), Conducting research (Google Scholar, Library Databases, ProQuest, etc., 72.0\%), and Searching/ accessing/using videos to support course content learning (68.8\%). The other technologies have percentages less than $50 \%$. 


\section{DISCUSSION}

Taken together, our findings suggest that introductory-level education courses can serve as spaces for PSTs to experience, experiment, and grow in their understanding of educational technologies, from both a skillacquisition and a social practice perspective. Beyond increases in their frequency of educational technology use and perceived proficiency, these findings also demonstrated positive relationships between these constructs and course outcomes as reported by students.

Situated within the broader context of related survey research, this study suggests some potential shifts in the experiences of PSTs with technology in their education courses. For example, while Project Tomorrow's (2013) study highlighted a discrepancy between current principal expectations of education technology proficiency and teacher reported experiences with such technologies, our study suggested that education courses can indeed be an important venue for PST engagement with educational technologies.

The present study demonstrated some resonance with existing research. For example, while Farjon et al.'s (2018) research suggested that experience with technology can be shown to be a statistically significant predictor of technology integration, our study suggested the potential of providing these additional experiences during teacher education coursework. Further, Erduran and Ince's (2018) work demonstrated that technical errors are among the main contributors to challenges in technology integration. Our study explored their suggestion of teacher education as one site for anticipating and supporting teachers through these challenges.

While our study provided some insight into PST's educational technology experiences within and beyond their education courses, it is important to interpret these results with caution, given the following limitations. First, the sample we selected reflected PSTs within a single institutional context. Additional research must be conducted to understand how these findings might transfer across different institutions and contexts. Also, the response rate in this study was low at less than $25 \%$ (i.e., 100 student participants over 406 PSTs) so the study findings may not accurately represent the perceptions of all PSTs. Additionally, our survey was primarily designed to rely on self-report measures, and caution should be taken not to interpret these findings as an "objective" measure of PST participation and skills in these areas. Further research may consider participant observation, experience sampling, focus groups, or related techniques to address this limitation and to triangulate the data. And though it was not the focus of this paper, the qualitative coding analysis we used to explore open-ended responses suggested additional work must be undertaken if stronger links between in-course technology experiences and outcomes are to be established. While we feel that these exploratory results are promising and insightful for our local context, further research must be done to determine whether the PSTs' perceived improvement was a result of their participation in the educational coursework, rather than other courses they might have taken, or other activities they might have participated in.

\section{CONCLUSION}

This paper highlighted how existing research has explored technology use in teacher education through the lens of self-efficacy, professional technology integration, belief patterns, technical proficiency, and reported behavior. Contributing to this body of work, we offered the present study as an additional empiricallygrounded account of PST technology use before and after a contemporary teacher education course, as well as the ways that this technology use might be connected to course outcomes and teacher learning. As technologies and their social uses are constantly in flux, our study contributes to an overall trajectory of research that helps to understand the nuances of these changes in educational technology integration. While additional work is needed to better understand the connections between PST technology experiences and beyond-course outcomes, the findings presented in this paper suggest several possibilities for improving the technology learning of PSTs in their educational coursework.

Author contributions: All authors were involved in concept, design, collection of data, interpretation, writing, and critically revising the article. All authors approve final version of the article.

Funding: The authors received no financial support for the research and/or authorship of this article.

Declaration of interest: Authors declare no competing interest.

Data availability: Data generated or analysed during this study are available from the authors on request. 


\section{REFERENCES}

Blair, J., Czaja, R. F., \& Blair, E. A. (2013). Designing surveys: A guide to decisions and procedures. Sage.

Cochran-Smith, M., \& Lytle, S. L. (2009). Inquiry as stance: Practitioner research for the next generation. Teachers College Press.

DuFour, R., \& Eaker, R. (2009). Professional learning communities at work: Best practices for enhancing students' achievement. Solution Tree Press.

Erduran, A., \& Ince, B. (2018). Identifying mathematics teachers' difficulties in technology integration in terms of Technological Pedagogical Content Knowledge (TPCK). International Journal of Research in Education and Science, 4(2), 555-576. https://doi.org/10.21890/ijres.428955

Farjon, D., Smits, A., \& Voogt, J. (2018). Technology integration of pre-service teachers explained by attitudes and beliefs, competency, access, and experience. Computers \& Education, 130, 81-93. https://doi.org/10.1016/j.compedu.2018.11.010

Gee, J. P. (2005). Semiotic social spaces and affinity spaces. In D. Barton \& K. Tusting (Eds.), Beyond communities of practice: Language, power, and social context (pp. 214-232). Cambridge University Press. https://doi.org/10.1017/CBO9780511610554.012

Groth-Marnat, G. (1999). Handbook of psychological assessment (3rd Ed.). John Wiley \& Sons.

Kirkwood, A., \& Price, L. (2014). Technology-enhanced learning and teaching in higher education: What is 'enhanced' and how do we know? A critical literature review. Learning, media and technology, 39(1), 6-36. https://doi.org/10.1080/17439884.2013.770404

Lave, J., \& Wenger, E. (1991). Situated learning: legitimate peripheral participation. Cambridge University Press. https://doi.org/10.1017/CBO9780511815355

Lei, J. (2009). Digital natives as preservice teachers: What technology preparation is needed? Journal of Computing in Teacher Education, 25(3), 87-97.

Mishra, P., \& Koehler, M. J. (2006). Technological pedagogical content knowledge: A framework for teacher knowledge. Teachers College Record, 108(6), 1017-1054. https://doi.org/10.1111/j.14679620.2006.00684.x

Project Tomorrow (2013). Learning in the 21st century: Digital experiences and expectations of tomorrow's teachers. https://tomorrow.org/speakup/tomorrowsteachers_report2013.html

Rogoff, B. (2003). The cultural nature of human development. Oxford University Press.

Serafini, F. (2000). Three paradigms of assessment: Measurement, procedure, and inquiry. The Reading Teacher, 54(4), 384-393.

Sfard, A. (1998). On two metaphors for learning and the dangers of choosing just one. Educational Researcher, 27(2), 4-13. https://doi.org/10.3102/0013189x027002004

Sung, Y. T., Chang, K. E., \& Liu, T. C. (2016). The effects of integrating mobile devices with teaching and learning on students' learning performance: A meta-analysis and research synthesis. Computers \& Education, 94, 252-275. https://doi.org/10.1016/j.compedu.2015.11.008

Thorkildsen, T. A. (2005). Fundamentals of measurement in applied research. Pearson, Allen Bacon.

Tondeur, J., Scherer, R., Baran, E., Siddiq, F., Valtonen, T., \& Sointu, E. (2019). Teacher educators as gatekeepers: Preparing the next generation of teachers for technology integration in education. British Journal of Educational Technology, 50(3), 1189-1209. https://doi.org/10.1111/bjet.12748 
Tüzün, H., Tepe, T., Güler, T. D., Özer, F., \& Uluçınar, V. (2017). Evaluating computer games for the professional development of teachers: The case of Atlantis remixed. International Journal of Virtual and Augmented Reality, 1(2), 60-74. https://doi.org/10.4018/IJVAR.2017070104

Wong, P. L., \& Glass, R. D. (2005). Assessing a professional development school approach to preparing teachers for urban schools serving low-income, culturally and linguistically diverse communities. Teacher Education Quarterly, 32(3), 63-77.

Correspondence: Trang Phan, California State University Fresno, Fresno, CA, USA.

E-mail: tphan@mail.fresnostate.edu 